\title{
A new somatic cell count index to more accurately predict milk yield losses
}

\author{
Janez Jeretina ${ }^{1}$, Dejan Škorjanc ${ }^{2}$, and Drago Babnik ${ }^{1}$ \\ ${ }^{1}$ Agricultural Institute of Slovenia, Hacquetova ulica 17, 1000 Ljubljana, Slovenia \\ ${ }^{2}$ University of Maribor, Faculty of Agriculture and Life Sciences, Pivola 10, 2311 Hoče, Slovenia \\ Correspondence to: Janez Jeretina (janez.jeretina@kis.si)
}

Received: 13 March 2017 - Revised: 28 August 2017 - Accepted: 7 September 2017 - Published: 16 October 2017

\begin{abstract}
Intramammary infection and clinical mastitis in dairy cows leads to considerable economic losses for farmers. The somatic cell concentration in cow's milk has been shown to be an excellent indicator for the prevalence of subclinical mastitis. In this study, a new somatic cell count index (SCCI) was proposed for the accurate prediction of milk yield losses caused by elevated somatic cell count (SCC). In all, 97238 lactations (55 207 Holstein cows) from 2328 herds were recorded between 2010 and 2014 under different scenarios (high and low levels of SCC, four lactation stages, different milk yield intensities, and parities $(1,2$, and $\geq 3)$. The standard shape of the curve for SCC was determined using completed standard lactations of healthy cows. The SCCI was defined as the sum of the differences between the measured interpolated values of the natural logarithm of SCC $(\ln (\mathrm{SCC}))$ and the values for the standard shape of the curve for SCC for a particular period, divided by the total area enclosed by the standard curve and upper limit of $\ln (\mathrm{SCC})=10$ for SCC. The phenotypic potential of milk yield (305-day milk yield - MY305) was calculated using regression coefficients estimated from the linear regression model for parity and breeding values of cows for milk yield. The extent of daily milk yield loss caused by increased SCC was found to be mainly related to the early stage of lactation. Depending on the possible scenarios, the estimated milk yield loss from MY305 for primiparous cows was at least 0.8 to $0.9 \mathrm{~kg} \mathrm{day}^{-1}$ and for multiparous cows it ranged from 1.3 to $4.3 \mathrm{~kg} \mathrm{day}^{-1}$. Thus, the SCCI was a suitable indicator for estimating daily milk yield losses associated with increased SCC and might provide farmers reliable information to take appropriate measures for ensuring good health of cows and reducing milk yield losses at the herd level.
\end{abstract}

\section{Introduction}

Development of intramammary infection (IMI) and occurrence of clinical mastitis in dairy cows leads to considerable economic losses for farmers (Nielsen et al., 2010; ElAwady et al., 2011), mainly owing to the reduction of milk production and lowering of milk technological traits (Bobbo et al., 2016). IMI has been shown to adversely affect fertility (Wolfenson et al., 2015) and reduce the longevity of dairy cows (Archer et al., 2013); it also increases the costs for implementation of veterinary services and extra labour.

The concentration of somatic cells in cow's milk has been shown to be an excellent and the main indicator for the estimation of the prevalence of subclinical mastitis. Cows with subclinical mastitis show no visible signs, but their somatic cell count (SCC, defined as the number of somatic cells per millilitre of milk) is elevated. Elevated SCC in milk suggests the presence of pathogens in the udder and is an indicator of IMI as well as a measure of the response to infection (Pyörälä, 2003; Heringstad et al., 2006). Thus, subclinical mastitis is considered as a hidden threat to healthy cows in a herd (Nyman et al., 2014).

For estimating the possible milk yield losses caused by subclinical mastitis, a definition of healthy or non-infected is essential. The threshold for a healthy udder was considered to be an SCC of $\leq 50000$ (Seegers et al., 2003) or approximately 70000 (Djabri et al., 2002; Schukken et al., 2003). Some authors defined a healthy animal as having a slightly higher SCC, i.e., $\leq 100000$ (Hand et al., 2012). Cows with an SCC of less than 100000 are considered to be non-infected, with no significant milk yield losses owing to subclinical 
mastitis. A new definition of subclinical mastitis assumed a new case if the SCC reached $>100000$ after a test day when the SCC was $<50000$ (Halasa et al., 2009). Therefore, the selection of an appropriate threshold for defining a noninfected udder depends on the purpose. At a lower threshold, more IMI (increased sensitivity and fewer false negatives) cases are identified, whereas the use of a higher threshold (increased specificity) might result in fewer false positives (Pantoja et al., 2009).

Together with high milk yield, the fat-to-protein ratio (FPR) can serve as an important risk factor for mastitis (Windig et al., 2005). Cows with mastitis are characterized by lower milk yield, elevated SCC, and a higher FPR (Jamrozik and Schaeffer, 2012). Thus, the FPR of milk was considered to be a suitable measure of the energy balance status of animals, especially during the initial and most metabolically stressful stage of lactation (Buttchereit et al., 2010).

A close association is known to exist between high milk yield and SCC. High-milk-yielding cows are more susceptible to mastitis (Jamrozik et al., 2010). The average SCCs calculated based on SCCs at different lactation stages are often used in mastitis control programs and in programs for the improvement of udder health. The drawback of using the lactation average of the SCCs is that it does not account for the SCC variability during lactation (De Hass et al., 2004). Variation in the shapes of the lactation curve during different lactation periods can be influenced by subclinical and/or clinical mastitis. Moreover, the types of pathogens associated with clinical mastitis occurrence can also differentially affect the lactation curve (De Hass et al., 2002). The early detection of elevated SCC during lactation is possible only by using test-day records. For detection of subclinical mastitis and possible IMI, comparing different test-day records of SCC is necessary. Timely detection and analysis of peaks in SCC during the different stages of lactation are important for the successful management of dairy farms.

However, considering the relationship between milk yield and SCC might lead to erroneous results since high milk yield might decrease the SCCs because of the dilution effect (Miller et al., 1993). The estimated SCCs of high-yielding dairy cows without IMI were found to be lower than those of low-yielding dairy cows (Green et al., 2006; Halasa et al., 2009; Boland et al., 2013). If the SCC concentration due to lower milk production in infected cows is neglected, the milk production loss might be overestimated. Overestimation of milk production loss can be avoided by using a dilution factor $\lambda$ for the adjustment of the yield and category of SCC (Green et al., 2006). Nevertheless, few previous studies could not completely clarify the relation between dilution effect and estimated milk loss.

Several other effects are also related to subclinical mastitis development and elevated SCCs. Numerous studies have shown that different factors, such as stage of lactation, subsequent parity (PAR), milk yield (Nielsen et al., 2010; Boland et al., 2013), calving month (Rupp and Boichard, 2000) and calving season, feeding and housing (Hortet and Seegers, 1998; Hagnestam-Nielsen et al., 2009), milking (Nyman et al., 2009), milk composition (Windig et al., 2005; Nyman et al., 2014), and test-day season, breed, pregnancy status, and health disorders, affect the SCC (Hagnestam-Nielsen et al., 2009). Subclinical mastitis is a very complex problem. Therefore, developing a simple, cost-effective, and efficient method for the estimation of the relationships between elevated SCC, subclinical mastitis, and potential milk yield loss in dairy cows is of great interest to the dairy sector.

Therefore, this study aimed to develop an index for excessive SCC, namely, the somatic cell count index (SCCI), for estimating the effect of subclinical mastitis on milk yield loss. Intervals of 30 days in milk test-day records were used to determine the relationships among SCC, calving year, calving season, age at the first calving, milk composition, stage of lactation, and milk yield; the effect of herd was also assigned for a more reliable prediction of milk yield losses.

\section{Materials and methods}

\subsection{Data sources and analyses}

In this study, 97238 standard lactation records of 55207 Holstein breed cows from 2328 herds were collected over 921594 test-days between 2010 and 2014. The data were a part of the national milk recording from the Slovenian database (Jeretina et al., 1997) collected according to the International Committee for Animal recording (ICAR, 2016). The average herd size was 32 cows. The test-day records with clinical mastitis were discarded from the data set. Lactations with at least seven milk recordings were truncated at 305 days. Each record of later analyses included the number of test-day milk yields (TDMYs, kg), FPR, PARs, stage of lactation (days in milk, DIMs), the season of calving ( $\mathrm{S}$; 1: spring, 2: summer, 3: autumn, and 4: winter), age at first calving (AFC, days), breeding values of cows for milk yield (BVAs), and $\operatorname{SCC}\left(\times 10^{3}\right)$.

The model was developed using two steps by using the statistical application R (R Development Core Team, 2016) and the lme4 libraries (Bates et al., 2015). In the first step, we determined the standard shapes of the curves for the natural logarithm of SCC during lactation in healthy cows for PAR 1,2 , and $\geq 3$ and estimated the phenotypic potential of milk yield for all cows to classify them into production groups. After that, we developed the SCCI for the estimation of SCC excess above the standard shape. In the second step, we analysed the effect of SCCI on milk yield loss for standard lactation according to the stage of lactation.

\subsubsection{Somatic cell count index}

We defined the SCCI for an individual lactation as the sum of the differences between the measured interpolated values of $\ln (\mathrm{SCC})$ (IP, Fig. 1) and the values of the standard shape of 


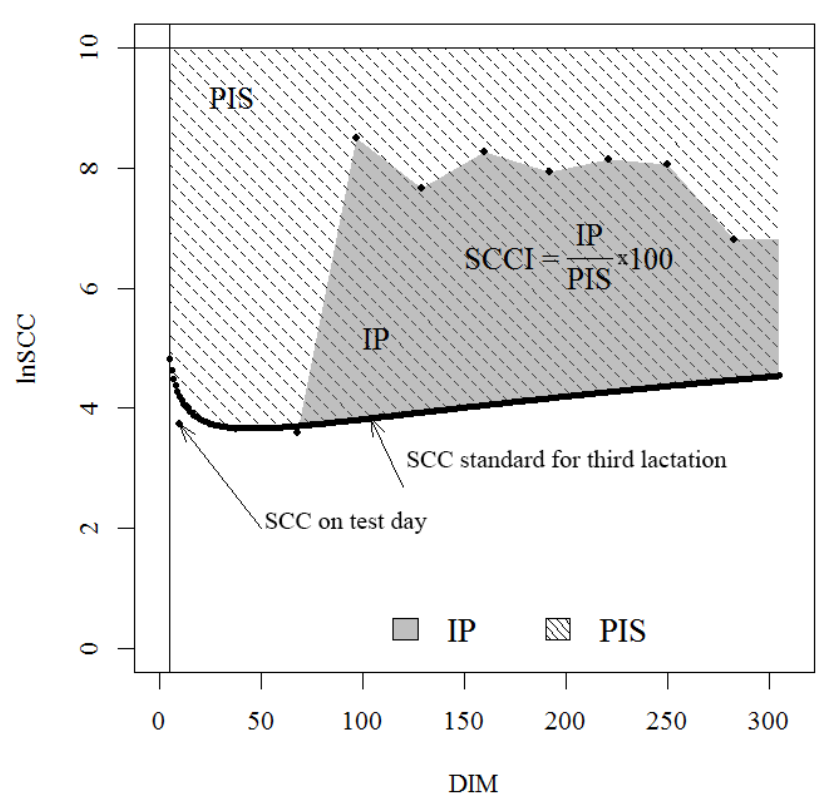

Figure 1. SCCI of a cow in the third lactation with somatic cell count (SCC) values on test days in relation to the standard shape of the curve for SCC. Jeretina et al. (2016).

the curve for SCC for a particular period, divided by the area above the standard shape of the curve for SCC (PIS, Fig. 1) (Eq. 1).

Therefore, the SCCI represents the area for IP in the percentage share of the total area for PIS above the standard shape of the curve for SCC (Fig. 1). By definition, the values of SCCI are between 0 and 100, wherein a value of 0 represents a small or inconsequential influence of SCC on milk yield for standard lactation, and 100 represents the maximal effect. When the SCCI was calculated, we considered the effect of dilution for high-milk-yielding cows without IMI. For cows with a daily milk yield above $10 \mathrm{~kg}$ and an SCC lower than 50000 , we performed a correction by using the factor -0.485 (Green et al., 2006). For calculation of the SCCI we used the following equation:

$$
\begin{aligned}
\mathrm{SCCI}= & \frac{\sum_{i=x_{1}}^{x_{2}}\left(\ln \mathrm{SCC}_{i}-\ln \mathrm{SCCM}_{i}\right)}{\sum_{i=5}^{305}\left(10-\ln \mathrm{SCCM}_{i}\right)} \times 100 \\
& \left\{\begin{array}{l}
\ln \mathrm{SCC}_{i}>\ln \mathrm{SCCM}_{i} \\
x_{1} \geq 5 \mathrm{DIM} \\
x_{2} \leq 305 \mathrm{DIM}
\end{array}\right.
\end{aligned}
$$

where the SCCI is the SCC index excess calculated for an optional interval between $x_{1}$ DIM and $x_{2}$ DIM, InSCCM is the natural logarithm of SCC for the standard shape of the curve at the $i$ th DIM, and InSCC is the natural logarithm of the measured SCC at the $i$ th DIM.
To determine the standard shape of the curve for SCC, we included the completed standard lactations (305-day milk yield - MY305) of cows for which the average SCC for standard lactation (ASCC) did not exceed 100000 SCC. This limit was set because in healthy cows, on the third day after calving, the SCC drops to 166000 and by the 10th day of lactation, it reduces to 100000 SCC (Barkema et al., 1999). In addition, we excluded the data for all cows in which the SCC between two consecutive milk recordings increased from less than 50000 to more than 100000 . These numbers potentially indicate a suspected case of subclinical mastitis (Halasa et al., 2009). We also excluded data for which the sum of squared deviations at fitting of lactation curves through TDMY in MY305 according to the MilkBot model (Cole et al., 2012) was larger than $150 \mathrm{~kg}$, which represents $>0.5 \mathrm{~kg}$ milk per production day.

We included fixed-effect PAR and the linear and quadratic regression effects of DIMs, which were used to explain the dependent variable $\ln (\mathrm{SCC} / 100)$, in the square regression model (Eq. 2).

$\ln \mathrm{SCCM}_{i j}=\mu+\mathrm{PAR}_{i}+\beta_{1} \times \mathrm{DIM}+\beta_{2} \times \mathrm{DIM}^{2}+e_{i j}$,

where $\operatorname{lnSCCM}$ is the natural logarithm of SCC; PAR is the $i$ th parity $(i=1,2, \geq 3) ; \beta_{1} \times \mathrm{DIM}$ and $\beta_{2} \times \mathrm{DIM}^{2}$ are the linear and quadratic regression effects of DIMs, respectively; and $e_{i j}$ is the residual effect.

\subsubsection{Predicting milk yield and classification in groups}

We calculated the phenotypic potential of milk yield for cows by using regression coefficients estimated from the linear regression model as follows:

$\mathrm{MY}_{305} 5_{i j}=\mu+\mathrm{PAR}_{i}+\beta_{1} \times \mathrm{BVA}+e_{i j}$,

where PAR is the fixed effect of parity $(i=1,2, \geq 3), \beta_{1}$ is the regression coefficient of BVA, and $e_{i j}$ is the residual of the model.

Based on the phenotypic potential of milk yield, we classified the cows into the following four classes: cows with the lowest - milk quantity $(\mathrm{MQ})=1-$ to the highest $(\mathrm{MQ}=4)$ MY305. We determined the size classes based on MQ with regard to the average of the predicted milk yield of the studied cattle population within specific PARs and by considering the sizes of the standard deviations.

\subsubsection{Estimation of the effect of SCCl on milk yield loss for standard lactation}

We investigated the effect of SCCI on milk yield loss for standard lactation within a particular month of lactation ( $\triangle \mathrm{MY} 30)$ and PAR for individual MQ by using multiple mixed regression models as follows: 


$$
\begin{aligned}
\Delta \mathrm{MY}_{i j k l m} & =\mu+Y_{i}+S_{j}+\beta_{1} \times \mathrm{AFC}+\beta_{2} \times \mathrm{BVA} \\
& +\beta_{3} \times \mathrm{FPR}+\beta_{4} \times \mathrm{SCCI}+h_{l}+e_{i j k l m},
\end{aligned}
$$

where $\Delta$ MY30 is the estimated milk yield loss within a particular month of lactation, calculated as a difference between the predicted (Jeretina et al., 2013) and the estimated milk yields on the test day for an individual month; $Y$ is the effect of calving year (2010-2014); $S$ is the effect of calving season (1-4); $\beta_{1}$ is the linear regression coefficient of AFC; $\beta_{2}$ is the linear regression coefficient of the $\mathrm{BVA} ; \beta_{3}$ is the linear regression coefficient of the FPR; $\beta_{4}$ is the linear regression coefficient of SCCI; $h$ is the random effect of $l$-herd; and $e_{i j k l m}$ is the residual of the model.

For milk yield loss on a daily basis $(\Delta \mathrm{MY})$, we used the linear model according to Ali and Schaeffer (AS; Ali and Schaeffer, 1987) to estimate the shape of the curve based on the SCCI points. Based on the estimated values of SCCI and DIMs within individual PARs and MQs, we used the following equation to predict $\triangle \mathrm{MY}$ for ASCC with 200000 , 300000 , and 400000 SCC:

$$
\begin{aligned}
\Delta \mathrm{MY} & =\sum_{\mathrm{DIM}=x_{1}}^{\mathrm{DIM}=x_{2}}\left(a+b \times\left(\frac{\mathrm{DIM}}{305}\right)+c \times\left(\frac{\mathrm{DIM}}{305}\right)^{2}\right. \\
& \left.+d \times \ln \left(\frac{305}{\mathrm{DIM}}\right)+k \times\left(\ln \left(\frac{305}{\mathrm{DIM}}\right)\right)^{2}\right) \\
& \times \mathrm{SCCI}_{\mathrm{DIM}} ; x_{1} \geq 5 ; x_{2} \leq 305,
\end{aligned}
$$

where $\triangle \mathrm{MY}$ is the predicted milk yield loss for any day or period between $x_{1}$ and $x_{2}$; parameters $a, b, c, d$, and $k$ are factors of the AS model; and SCCI DIM is the SCC index excess for a particular day of DIMs.

\subsubsection{Impact of somatic cell count level within specific PARs, lactation interval, and milk production level on milk yield loss}

To determine the effect of IMI on $\Delta \mathrm{MY}$ at different stages of lactation, we used the data for cows from the cattle population that exhibited average values of $200000 \pm 50000$, $300000 \pm 50000$, or $400000 \pm 50000$ ASCC for standard lactation. The lactation period was divided into four lactation intervals (LIs; LI1 = 0-80 DIMs, LI2 $=81-160$ DIMs, LI3 $=161-240$ DIMs, and LI4 $=241-305$ DIMs), and $\Delta \mathrm{MY}$ was calculated for each period. An individual LI with $\mathrm{SCCI} \leq 5 \%$ was considered as a period of lactation with a low increase in SCC; above this value, the lactation period was considered to show a high increase in SCC. Individual effects on $\triangle \mathrm{MY} 305$ were estimated using the following multiple linear regression model (Eq. 6):

$$
\begin{aligned}
\Delta \mathrm{MY}^{305_{i j k l m}} & =\mu+\mathrm{PAR}_{i}+\mathrm{MQ}_{j}+\mathrm{VAR}_{k}+\mathrm{ASCC}_{l} \\
& +e_{i j k l m},
\end{aligned}
$$

where $\triangle \mathrm{MY} 305$ is the $\triangle \mathrm{MY}$ in standard lactation, PAR is the $i$ th parity $(i=1,2$, and $\geq 3)$, MQ $(j=1-4)$ is the level of potential milk production (see Table 2$)$, VAR $(k=1-8)$ represents eight different scenarios regarding the effect of a low or high level of SCCI within each of the four LIs (see Table 5), ASCC is the average SCC (200000, 300000 , or $400000 \mathrm{SCC}$ ), and $e_{i j k l m}$ is the residual of the model.

\section{Results and discussion}

The number of completed lactations with the average MY305, protein and fat contents in milk, and the average geometric mean of SCC per lactation are shown in Table 1. The average MY305 of primiparous cows, which was $40 \%$ of all lactations in the analysis, was $6828 \mathrm{~kg}$ with $122000 \mathrm{SCC}$, and that in the second lactation was $7622 \mathrm{~kg}$ with 158000 SCC. In the later lactations, the milk yield was $7808 \mathrm{~kg}$ with 236000 SCC.

To estimate the effect of SCCI on $\triangle \mathrm{MY}$, we used the linear AS model and assessed the value of the SCCI depending on DIMs. The parameters of the curve for individual PAR and MQ are shown in Table 2.

The corresponding parameter values (Table 2) were included in Eq. (5) and $\triangle \mathrm{MY}$ values were calculated for different SCCs for any day or period. A representative estimation of the daily milk yield loss in kilogram per stage of lactation (DIM) and MQ for the consecutive PAR is shown in Fig. 2.

The results showed that in primiparous cows the regression influence of SCC on $\triangle \mathrm{MY}$ was the lowest within 7 to 10 weeks after calving. It coincided with the peak of lactation in primiparous cows. Our results are in good agreement with those of a previous published study by Hagnestam-Nielsen et al. (2009). They set the limit between 3 and 8 weeks after calving for primiparous cows and between 3 and 16 weeks for later lactations. In the early stage of the second lactation, the smallest influence of SCC on $\triangle \mathrm{MY}$ was noted between 8 and 10 weeks after calving. However, this was observed only in the case of high-milk-yielding cows $(\mathrm{MQ}=3$ and 4). Interestingly, this effect was also not found in the case of subsequent lactations. Unexpectedly, when the SCC was constant, its effect on milk yield was not the highest during the early stage of lactation. This can be attributed to the physiology and functionality of the udder gland. The mammary epithelial cells secrete the highest amount of milk during this period; a similar finding was noted for cell renewal capacity. During this period, the process of apoptosis is only initiated in the udder gland (Knight and Wilde, 1993). Therefore, IMI does not have a marked effect on milk yield loss. Notably, this is evident for primiparous cows, the mammary glands of which do not have a history of IMI. Another possibility is the high uncertainty related to the estimation of yield loss during early lactation because of the limited number of milk recordings. In this short period, the right type of model for the assessment of the shape of lactation curve after calving cannot be accurately selected, which might also undervalue 


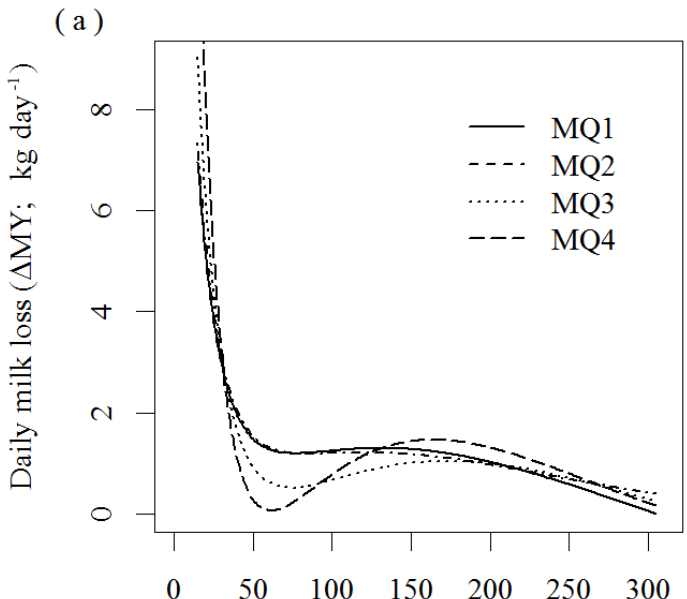

( b )

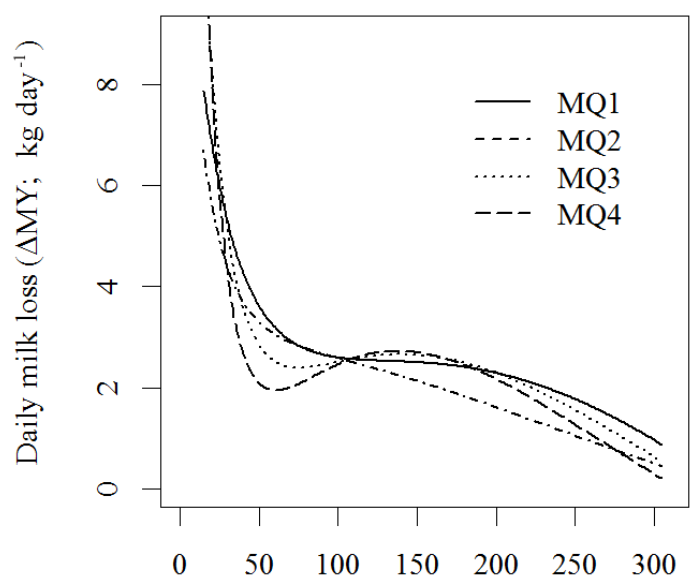

(c)

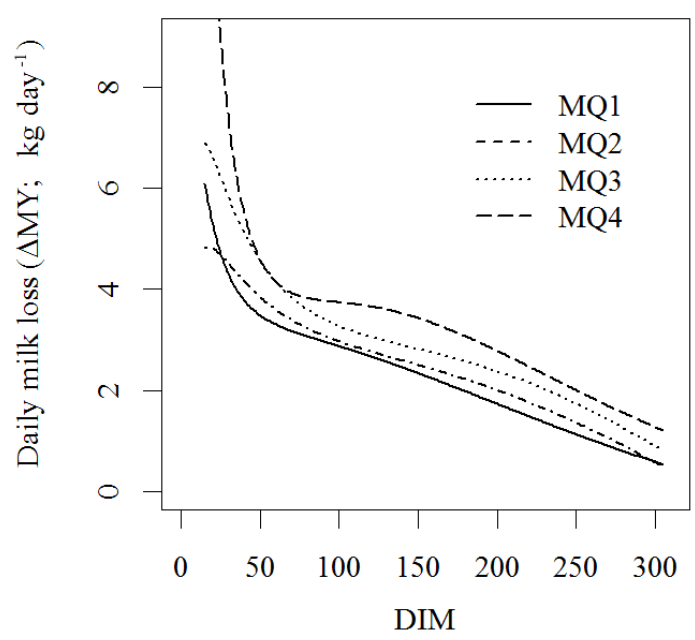

Figure 2. Estimated daily milk yield loss $\left(\mathrm{kg} \mathrm{DIM}^{-1}\right)$ for different milk production levels (MQ) and the specific value of 300000 somatic cell count (SCC) in consecutive lactations - (a) first parity, (b) second parity, and (c) $\geq$ third parity. Jeretina et al. (2016). the level and time of the peak lactation achieved (Elahi Torshizi et al., 2011).

About $77 \%$ of the variance in milk yield loss caused by SCC could be explained by the effects such as subsequent PAR, MQ, LI, and ASCC (Tables 3 and 4).

For consecutive lactations, the model explained almost $44 \%$ of the variability in milk yield loss $(P<0.01$, Table 4$)$. It is evident that milk loss is related to subsequent lactation. The estimated mean values for PAR2 and PAR3 represented 285.1 and $333.8 \mathrm{~kg}$ of additional loss of milk compared to PAR1 (Table 3). Although MQ explains only a small proportion of the variance in the model $(2.2 \%)$, the differences in milk yield loss between cows with different milk yields were statistically significant. The LI in the model explained $19.3 \%$ of the variability in milk yield losses ( $\triangle \mathrm{MY})$ by SCC. It is an important factor that influences the prediction of milk yield loss during lactation. The worst scenario (VAR5 to VAR7) regarding milk loss was when the SCC was high during the first interval of lactation (0-80 days, Table 3 ). In this case, reaching the normal lactation curve is impossible even in the case when the health of the udder is speculated to improve during later stages of lactation. In addition, the ASCC remarkably affected the explanation of variability. For standard lactation, the ASCC was often used for mutual comparison of cows with regard to the level of SCC that caused adverse effects and to predict $\triangle \mathrm{MY}$ on a daily basis. The ASCC accounted for $11.6 \%$ of the variability in milk yield loss caused by SCC.

Based on their literature review, Hortet and Seegers (1998) reported that in published studies 38 to $84 \%$ of variability in milk yield loss at the test-day level was explained by regression models. Most of previously reported regression models can explain about 63 to $84 \%$ of variability; thus, the $77 \%$ variability explained in the present study is in good agreement with the findings of previous studies. In this study, in agreement with the findings of literature reports, a significant herd effect was noted on the investigated characteristics (data not presented). The herd effect was highly significant in milk composition and SCC even in studies that included low numbers of herds, i.e., with only two commercial herds with 149 and 106 Holstein cows per herd (Friggens and Rasmussen, 2001), 12 to 58 herds with $\geq 80$ cows per herd of Swedish Holstein and Swedish Red breeds (Nyman et al., 2009), and 85 herds of Brown Swiss with a maximum of 15 cows per herd (Bobbo et al., 2016).

In the present study, the SCC was adjusted using a dilution factor, $\lambda$. A dilution factor of -0.485 , according to Green et al. (2006), was applied for SCC only for those cows that had more than $10 \mathrm{~kg}$ of daily milk yield and an SCC of $<50000$. Only a few studies proposed the existence of the dilution effect from increased milk yield on the SCC (at the level of 200000 ) in cows without IMI. High-milk-yielding cows without IMI have been thought to exhibit lower SCC than low-milk-yielding cows (Miller et al., 1993; Green et al., 2006; Halasa et al., 2009). Dilution-adjusted SCC values fitted the data better and resulted in a slightly reduced milk loss 
Table 1. Some descriptive statistics of data: number of lactations, average milk yield in standard lactation (MY305, kg), fat (\% F), protein $(\% \mathrm{P})$, and geometric mean of the somatic cell count (SCC).

\begin{tabular}{|c|c|c|c|c|c|c|c|c|c|}
\hline \multirow[t]{2}{*}{ Parity } & \multirow{2}{*}{$\begin{array}{c}\text { Number of } \\
\text { lactations }\end{array}$} & \multicolumn{2}{|c|}{ MY305 } & \multicolumn{2}{|l|}{$\% \mathrm{~F}$} & \multicolumn{2}{|l|}{$\% \mathrm{P}$} & \multicolumn{2}{|c|}{$\mathrm{SCC}\left(\times 10^{3}\right)$} \\
\hline & & $\bar{x}$ & SD & $\bar{x}$ & SD & $\bar{x}$ & $\mathrm{SD}$ & $\bar{x}$ & $\mathrm{SD}$ \\
\hline 1 & 33488 & 6828 & 1453 & 4.00 & 0.50 & 3.30 & 0.24 & 122 & 3.1 \\
\hline 2 & 25276 & 7622 & 1778 & 4.07 & 0.55 & 3.39 & 0.27 & 158 & 3.2 \\
\hline$\geq 3$ & 38474 & 7808 & 1823 & 4.01 & 0.53 & 3.30 & 0.25 & 236 & 3.3 \\
\hline
\end{tabular}

$\bar{x}$ : average. SD: standard deviation.

Table 2. Regression coefficients calculated using Eq. (5) (Ali and Schaeffer, 1987) within parities (PARs) and the rank of milk production level (MQ) for the somatic cell count index estimation according to the stage of lactation.

\begin{tabular}{rrrrrrrr}
\hline PAR & MQ & Range of milk & \multicolumn{5}{c}{ Calculated regression coefficients } \\
\cline { 3 - 7 } & & $\mathrm{kg}$ & $a$ & $b$ & $c$ & $d$ & $k$ \\
\hline 1 & 1 & $\leq 4500$ & 236.5 & -259.7 & 23.3 & -172.7 & 39.5 \\
& 2 & $4501-6500$ & 286.7 & -347.5 & 65.7 & -201.9 & 44.6 \\
& 3 & $6501-8500$ & 293.9 & -322.0 & 31.1 & -226.4 & 53.5 \\
& 4 & $>8500$ & 697.5 & -844.2 & 148.7 & -507.1 & 108.9 \\
2 & 1 & $\leq 5500$ & -66.2 & 199.1 & -121.2 & 26.9 & 5.5 \\
& 2 & $5501-7500$ & 159.6 & -166.1 & 12.5 & -102 & 24.1 \\
& 3 & $7501-9500$ & 338.7 & -335.2 & 3.7 & -252.8 & 60.1 \\
& 4 & $>9500$ & 600.5 & -694.5 & 96.7 & -425.6 & 90.9 \\
$\geq 3$ & 1 & $\leq 6000$ & 189.6 & -207.7 & 26.3 & -115.5 & 25.4 \\
& 2 & $6001-8000$ & -104.4 & 224.1 & -112.1 & 73.3 & -8.6 \\
& 3 & $8001-10000$ & -148.3 & 305.2 & -144.6 & 95.0 & -9.1 \\
& 4 & $>10000$ & 563.0 & -654.1 & 109.6 & -387.7 & 86.4 \\
\hline
\end{tabular}

Table 3. Sources of variation for milk yield loss estimation included in the linear regression model with standard errors (SEs), $t$ values, and $P$ values.

\begin{tabular}{|c|c|c|c|c|}
\hline Effects $^{\mathrm{a}}$ & Mean & SEs & $t$ value & $P$ value \\
\hline Intercept & 156.4 & 4.1 & 37.81 & $<0.01$ \\
\hline PAR2 & 285.1 & 2.2 & 127.21 & $<0.01$ \\
\hline PAR3 & 333.8 & 2.4 & 136.73 & $<0.01$ \\
\hline MQ2 & -7.9 & 3.2 & -2.52 & $<0.05$ \\
\hline MQ3 & 55.3 & 3.2 & 17.24 & $<0.01$ \\
\hline MQ4 & 91.9 & 3.9 & 23.81 & $<0.01$ \\
\hline VAR $2^{b}$ & 176.5 & 3.6 & 48.45 & $<0.01$ \\
\hline VAR3 & 46.6 & 4.3 & 10.87 & $<0.01$ \\
\hline VAR4 & 37.4 & 3.8 & 9.90 & $<0.01$ \\
\hline $\mathrm{VAR}^{\mathrm{b}, \mathrm{c}}$ & 181.1 & 6.2 & 29.31 & $<0.01$ \\
\hline VAR $6^{b, c}$ & 179.0 & 5.8 & 30.99 & $<0.01$ \\
\hline VAR7 $7^{\mathrm{c}}$ & 184.5 & 3.9 & 47.92 & $<0.01$ \\
\hline VAR8 & 145.2 & 3.9 & 37.55 & $<0.01$ \\
\hline ASCC 300 & 138.2 & 2.5 & 55.37 & $<0.01$ \\
\hline ASCC400 & 248.6 & 3.2 & 78.97 & $<0.01$ \\
\hline Adj. R2 & 0.77 & & & \\
\hline
\end{tabular}

a PAR: parity. MQ: milk production levels. VAR: scenarios. ASCC: average somatic cell count. ${ }^{b, c}$ Mean values with the same letters indicate non-significance $(P>0.05)$.
Table 4. Analysis of variance ${ }^{1}$ for milk yield loss by somatic cell count effect.

\begin{tabular}{lrrrrr}
\hline Effect & DF & SS & SS $\%$ & $F$ value & $P$ value \\
\hline PAR & 2 & 305554556 & 43.6 & 12734.67 & $<0.01$ \\
MQ & 3 & 15716222 & 2.2 & 436.67 & $<0.01$ \\
VAR & 7 & 135111629 & 19.3 & 1608.88 & $<0.01$ \\
ASCC & 2 & 81167063 & 11.6 & 3382.82 & $<0.01$ \\
Residuals & 13586 & 162990641 & 23.3 & & \\
\hline
\end{tabular}

${ }^{1}$ PAR: parities. MQ: milk production levels. VAR: scenarios. ASCC: average somatic cell count. DF: degree of freedom. SS: sum of squares. SS \%: percentage of explained variability of the whole model.

compared to the unadjusted SCC (Green et al., 2006). Contrary to the findings of previous studies, Boland et al. (2013) found no dilution effect on the SCC in the Irish dairy cattle; this was more evident in the low-SCC category $(<200000)$ in which adjustment for dilution yielded similar results as those for the unadjusted model.

Cows with an SCC of $\leq 100000$ were considered as a reference group. Two steps were adapted: first, standard lactation curves were generated for specific milk yield (Jeretina et al., 2013); next, a standard curve of SCC in healthy cows with 1,2 , and $\geq 3$ lactations was developed. In this study, an expected milk yield for standard lactation $\mathrm{MY}_{305} 5_{i j}$ was esti- 
mated for each cow. The expected milk yield of $j$-cows was equal to the population mean value corrected to the subsequent parity $\mathrm{PAR}_{i}$ and regression of BVA. This estimation was under the assumption that all fixed and random effects showed normal distribution with a mean value of 0 and were not under other environmental effects. From this curve, predictions for daily milk production were obtained. For each 30-day interval after calving, the test interval method (ICAR) was used to predict the milk yield, and this value was obtained from the area below the expected curve of milk yield.

The duration of subclinical mastitis was described using the SCCI, for which the area (IP) above the standard curve for SCC was used. The size of the area depended on the duration and intensity of the subclinical mastitis. In addition, all incidences for the increase in SCC were used for the prediction of the SCCI. Within each 30-day interval, the effect of the SCCI was estimated as the regression for 1,2 , and $\geq 3$ lactations for four milk production levels (MQ). The mean values of regression of the SCCI (10 points in standard lactation) were used to generate the SCCI curve. The milk yield loss over a specific interval with increased SCC was computed. In this study, the prolonged effect of subclinical mastitis was not adjusted. Reduction of milk could be partly compensated for by other quarters within the udder (Holdaway, 1990), but it depended on the level of infection and stage of lactation, as well as the type of pathogen (Schepers et al., 1997; De Haas et al., 2002, 2004). In the present study, all milk samples with extremely changed characteristics were excluded from further analyses. In addition, each case of clinical mastitis on the test day was not included in the analysis. Because such information was not collected systematically in the regular milk recording system (AT method, according to the ICAR), in the period between two controls, some data regarding clinical mastitis presence might not have been collected. The possible carry-over effect of clinical mastitis from previous lactation was avoided by using the SCC measured for the previous milk control before dry-off. This effect was not significant and was later excluded from the model.

A specific cyclic nature of infection of mammary glands in the data collected was presumed form the estimated SCCI in relation to the eight different scenarios (high or low levels of SCC in four lactation stages for different parities) an equal average SCC was determined for the milk yield loss across these scenarios. The SCCI enables the investigation of different situations related to varying SCCs at different lactation stages, milk intensities, and subsequent PARs (Table 5). It has been demonstrated that milk yield loss is related to the lactation stage at which the elevated SCC appears. This means that milk yield loss cannot be reliably estimated on the basis of average SCC. Information on the course of events is needed. A too-long interval between test-day controls is a period with a lack of information. During this period, subclinical mastitis could heal spontaneously or progress to clinical mastitis and thus lead to an elevated SCC. Determining the number of days before or after the diagnosis of subclinical mastitis is important for clinical mastitis detection. Such data can be accurately obtained on an experimental farm or by using a systematic collection of data on medical treatments by veterinarians and breeders, as in some countries (Scandinavian countries, Austria).

It is questionable whether management conditions on experimental farms (Lescourret and Coulon, 1994) are appropriate and comparable with larger numbers of commercial farms (Windig et al., 2005) to study applicable methods for the detection of subclinical mastitis and its effect on milk yield loss in field conditions. Hortet and Seegers (1998) reviewed selected literature on milk yield loss, milk composition, and elevated SCCs. Prediction of milk yield loss can be affected by several factors such as differences in the methodology used for preparing data sets and calculations; the specific design of studies regarding the number and interval between test-day controls; the number and size of investigated farms, herds, and types of farms (experimental vs. commercial); housing systems; number of PARs; duration of lactation; and threshold of SCCs for subclinical mastitis. Therefore, comparing our results (Table 5) regarding the effect of elevated SCC and lactation period, subsequent PAR, milk yield, and different scenarios within standard lactation on reduced milk production with those of literature findings is difficult.

A threshold of 200000 SCC would suggest that a cow has IMI and is likely to be infected for at least an udder quarter. Across studies primiparous cows with 200000 SCC showed, in kilograms per day, a milk loss of 0.13 (Boland et al., 2013), 0.23 to 1.76 (Rekik et al., 2008), 0.28 (Halasa et al., 2009), 0.61 (Hortet et al., 1999), 0.46 to 0.72 (Dürr et al., 2008), 0.35 to 0.80 (Hand et al., 2012). The results of the present study for thresholds of 200000 and 400000 SCC predicted higher milk yield losses in the range of 0.8 to 1.4 and 1.0 to $2.7 \mathrm{~kg} \mathrm{day}^{-1}$, respectively. The seriousness of the effect of SCC increase on milk yield loss from various studies is difficult to compare directly. This is due to the SCC range and model approach, different baseline that divides healthy from unhealthy cows, dilution adjustment, different stage of lactation in which IMI occurred, production practises, and differences due to geographic area in the relative importance of different mastitis pathogens. Depending on the possible scenario, VAR2 to VAR4 (Table 5), our estimated milk yield loss for primiparous cows was at least 0.8 to $0.9 \mathrm{~kg} \mathrm{day}^{-1}$ at the level of 200000 SCC. Higher milk yield loss was predicted at the same threshold of SCC but for other scenarios. High SCC during the first 80 days of lactation had a strong impact on the increase in milk yield loss, which was estimated to be 1.2 to $1.4 \mathrm{~kg} \mathrm{day}^{-1}$ (VAR1 and VAR5 to VAR7). Even in the case when the SCC dropped later during lactation to a value lower than our estimation, milk yield reduction was at least $1.2 \mathrm{~kg} \mathrm{day}^{-1}$. These findings regarding the effect of elevated SCC early during lactation and its impact on milk yield loss for an extended period are in agreement with those reported previously. During the period when the SCC peaked, 
Table 5. Daily milk yield loss ( $\triangle \mathrm{MY}, \mathrm{kg}$ ) in various scenarios (VAR) of somatic cell index (SCCI) (H - high, $\mathrm{L}-$ low) according to lactation intervals (LI1 $=0-80$, LI2 $=81-160$, LI3 $=161-240$, LI4 $=241-305$ days in milk) within parity, milk production level (MQ), and level of average SCC $\left(\times 10^{3}\right)($ ASCC).

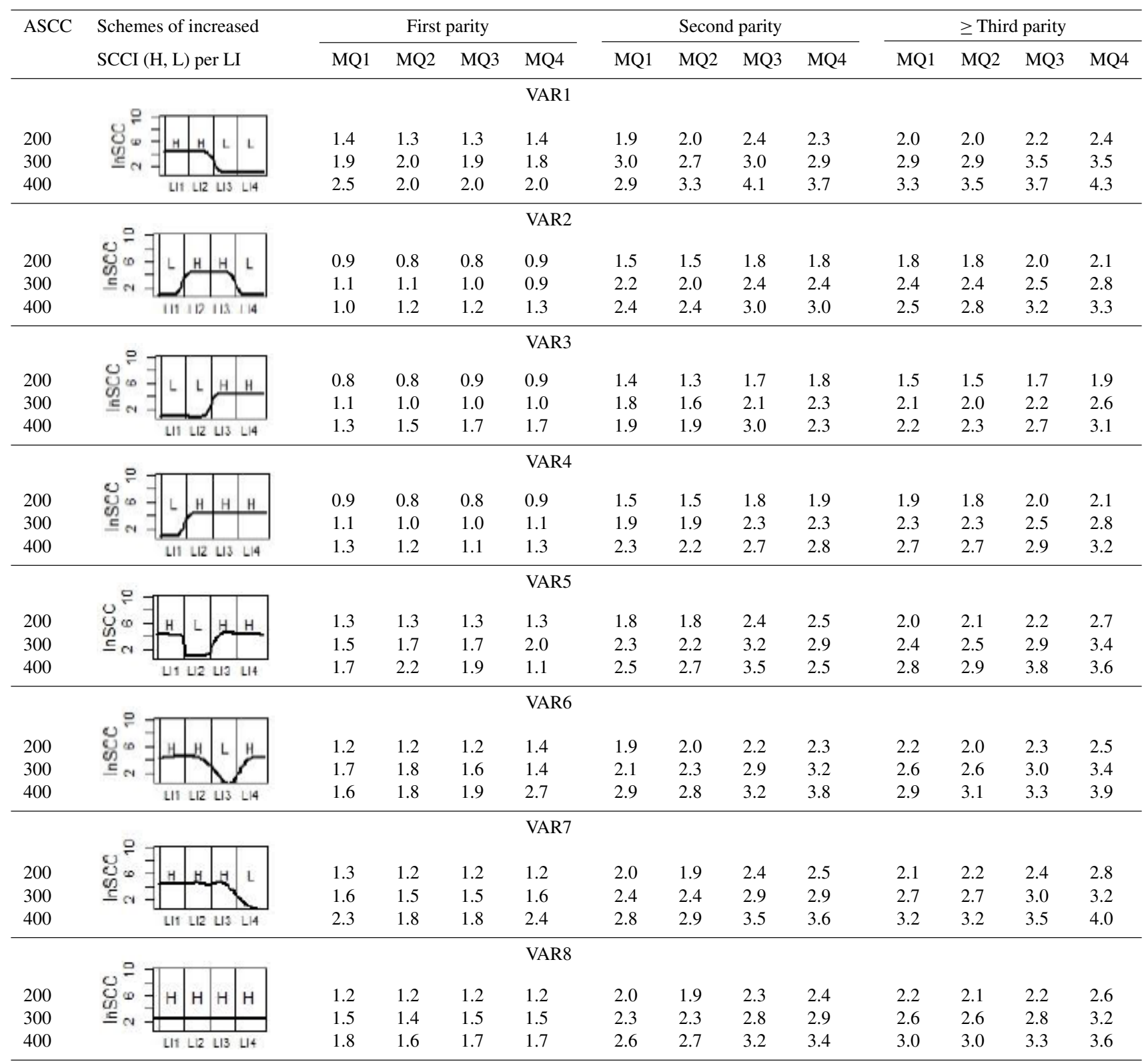

the milk yield dropped and did not reach the pre-peak levels (Windig et al., 2005). During early lactation, mastitis development had a substantial effect on reduced milk yield when milk loss was noted for an extended period during the entire lactation (Lescourret and Coulon, 1994).

In the second and/or third and subsequent PARs, elevated SCC led to milk yield losses. Studies show, in kilograms per day, milk yield losses of 0.63 to 1.17 and from 0.60 to 1.85 for PAR2 and PAR $\geq 3$ (Hortet et el., 1999), 0.50 for PAR $\geq 2$ (Halasa et al., 2009), 0.6 for PAR $\geq 2$ (Hortet and Seegers, 1998), 1.05 to 2.50 for PAR $\geq 2$ (Dürr et al., 2008), and 0.61 to 1.07 and 0.63 to 1.09 for PAR2 and PAR $\geq 3$ (Hand et al., 2012). Our predicted values for milk yield loss in PAR2 and PAR $\geq 3$ ranged from 1.3 to 2.5 and 1.5 to $2.8 \mathrm{~kg} \mathrm{day}^{-1}$, respectively. An elevated SCC of 400000 in subsequent lactations was found to be significantly associated with the loss of milk yield in many studies. In studies, reported daily milk yield loss at an SCC of 400000 ranged from 0.78 for PAR $\geq 2$ (Halasa et al., 2009) to 1.0-3.0 for $\mathrm{PAR} \geq 2$, and from 1.58 to 3.74 for PAR $\geq 2$ (Dürr al., 2008). Exceptions to the studies above are Dürr et al. (2008) and Hand et al. (2012) and our estimated milk yield loss are very 
close to theirs. Nevertheless, differences in milk yield loss existed even in all cases. One explanation for this discrepancy is the threshold, a lower limit at which SCC could affect the loss of milk yield owing to IMI. Dürr et al. (2008) set the limit for subclinical mastitis at more than 7400 SCC, Hand et al. (2012) at 200000 , and in our study more than 100000 SCC with additional specific limitations. Various lower limits of SCC over a broad range have been proposed in previous studies: 51000 to more than 1000000 in PAR of one to four (Boland et al., 2013), 31000 to more than 400000 (Green et al., 2006), less than 200000 (Rekik et al., 2008), 100000 to 600000 (Hortet et al., 1999), and 500000 for primiparous and multiparous cows (Hagnestam-Nielsen et al., 2009). In some higher classes, the ranges were from less than 200000 to 1000000 SCC with milk yield loss of 0.387 to $2.351 \mathrm{~kg} \mathrm{day}^{-1}$ (Guo et al., 2010), 403000 to $1900000 \mathrm{SCC}$ with 0.6 to $3.8 \mathrm{~kg}$ estimated milk yield loss (Yalçin et al., 2000), and 200000 to 2000000 SCC with a reduction of milk production of $0.35-1.09 \mathrm{~kg} \mathrm{day}^{-1}$ to $1.49-$ $4.70 \mathrm{~kg} \mathrm{day}^{-1}$ (Hand et al., 2012). Another possible problem for comparison is the average milk yield in the population of the investigated cows. In this study, lower milk yield for standard lactation and higher variability for this trait was observed, unlike that in previous studies. Furthermore, not only genetic differences but also a probable lower level of herd management could be responsible for the variation in the predicted milk yield loss.

In the present study, elevated SCC had a higher effect on milk yield loss in multiparous than in primiparous cows. Multiparous cows in late lactation might be responsible for the majority of milk production loss at the herd level caused by elevated SCC (Hagnestam-Nielsen et al., 2009). Moreover, if milk losses owing to subclinical mastitis were not estimated appropriately, i.e., by using average loss per lactation, milk loss could be overestimated in the beginning of lactation, thereby remarkably underestimating losses toward the end of lactation (Dürr et al., 2008). Therefore, the SCCI developed in the present study allows corrections for the estimation of milk loss in the population of Holstein cows. Furthermore, it is applicable to other cow populations, but the standard curves and breeding value prediction methods for specific cow populations need to be determined.

\section{Conclusions}

Improving herd management requires the recognition of the dynamics and peaks of elevated somatic cell count with relation to daily milk loss during lactation. A standard of the average somatic cell count as a criterion for comparing cows with regard to the health status of their udder glands does not allow identification of time-related consequences of IMI for cow and herd management. The newly introduced somatic cell count index might enable the mutual comparison of milk yield loss across cows in relation to the level of SCC, effect of consecutive parity, stage of lactations, and milk yield intensity. The SCCI has been proposed as an indicator of IMI to provide farmers reliable information to apply appropriate measures regarding cow health management and overall economical cow milk production.

Data availability. The data of the paper are available upon request from the corresponding author.

Author contributions. JJ and DB designed the experiment. JJ analysed the data, and DŠ drafted the paper.

Competing interests. The authors declare that they have no conflicts of interest.

Acknowledgements. The comments and suggestions of the three anonymous referees are greatly appreciated. The authors would like to thank the Slovenian Research Agency for the financial support (P1-0164, P4-0133).

Edited by: Nina Melzer

Reviewed by: Muhamed Brka and one anonymous referee

\section{References}

Ali, T. E. and Schaeffer, L. R.: Accounting for covariances among test day milk yields in dairy cows, J. Anim. Sci., 67, 637-644, 1987.

Archer, S. C., Mc Coy, F., Wapenaar, W., and Green, M. J.: Association between somatic cell count early in the first lactation and the lifetime milk yield of cows in Irish dairy herds, J. Dairy Sci., 96, 2951-2959, 2013.

Barkema, H. W., Deluyker, H. A., Schukken, Y. H., and Lam, T.: Quarter-milk somatic cell count at calving and at the first six milkings after calving, Prev. Vet. Med., 38, 1-9, 1999.

Bates, D., Maechler, M., Bolker, B., Walker, S.: Fitting linear mixed-effects models using lme4, J. Stat. Softw., 67, 1-48, 2015.

Bobbo, T., Cipolat-Gotet, C., Bittante, G., and Cecchinato, A.: The nonlinear effect of somatic cell count on milk composition, coagulation properties, curd firmness modelling, cheese yield, and curd nutrient recovery, J. Dairy Sci., 99, 5104-5119, 2016.

Boland, F., O'Grady, L., and More, S. J.: Investigating a dilution effect between somatic cell count and milk yield and estimating milk production losses in Irish dairy cattle, J. Dairy Sci., 96, 1477-1484, 2013.

Buttchereit, N., Stamer, E., Junge, W., and Thaller, G.: Evaluation of five lactation curve models fitted for fat: protein ratio of milk and daily energy balance, J. Dairy Sci., 93, 1702-1712, 2010.

Cole, J. B., Ehrlich, J. L., and Null, D. J.: Short communication: projecting milk yield using best prediction and the MilkBot lactation model, J. Dairy Sci., 95, 4041-4044, 2012.

De Haas, Y., Veerkamp, R. F., Barkema, H. W., Gröhn, Y. T., and Schukken, Y. H.: Associations between pathogen-specific cases 
of clinical mastitis and somatic cell count patterns, J. Dairy Sci., 87, 95-105, 2004.

De Hass, Y., Barkema, H. W., and Veerkamp, R. F.: The effect of pathogen-specific clinical mastitis on the lactation curve for somatic cell count, J. Dairy Sci., 85, 1314-1323, 2002.

Djabri, B., Bareille, N., Beaudeau, F., and Seegers, H.: Quarter milk somatic cell count in infected dairy cows: a meta-analysis, Vet. Res., 33, 335-357, 2002.

Dürr, J. W., Cue, R. I., Monardes, H. G., Moro-Méndez, J., and Wade, K. M.: Milk loss associated with somatic cell counts per breed, parity and stage of lactation in Canadian dairy cattle, Livest. Sci., 117, 225-232, 2008.

Elahi Torshizi, M., Aslamenejad, A. A., Nassiri, M. R., and Farhangfar, H.: Comparison and evaluation of mathematical lactation curve functions of Iranian primiparous Holsteins, S. Afr. J. Anim. Sci., 41, 104-115, 2011.

El-Awady, H. G. and Oudah, E. Z. M.: Genetic and economic analysis for the relationship between udder health and milk production traits in Friesian cows, Asian-Aust. J. Anim. Sci., 24, 1514-1524, 2011.

Friggens, N. C. and Rasmussen, M. D.: Milk quality assessment in automatic milking systems: accounting for the effects of variable intervals between milkings on milk composition, Livest. Prod. Sci., 73, 45-54, 2001.

Green, L. E., Schukken, Y. H., and Green, M. J.: On distinguishing cause and consequence: do high somatic cell counts lead to lower milk yield or does high milk yield lead to lower somatic cell count?, Prev. Vet. Med., 76, 74-89, 2006.

Guo, J., Liu, X., Xu, A., and Xia, Z.: Relationship of somatic cell count with milk yield and composition in Chinese Holstein population, Agric. Sci. China, 9, 1491-1496, 2010.

Hagnestam-Nielsen, C., Emanuelson, U., Berglund, B., and Strandberg, E.: Relationship between somatic cell count and milk yield in different stages of lactation, J. Dairy Sci., 92, 3124-3133, 2009.

Halasa, T., Nielen, M., De Roos, A. P. W., Van Hoorne, R., De Jong, G., Lam, T. J. G. M., Van Werven, T., and Hogeveen, H.: Production loss due to new subclinical mastitis in Dutch dairy cows estimated with a test-day model, J. Dairy Sci., 92, 599-606, 2009.

Hand, K. J., Godkin, A., and Kelton, D. F.: Milk production and somatic cell counts: a cow-level analysis, J. Dairy Sci., 95, 13581362, 2012.

Heringstad, B., Gianola, D., Chang, Y. M., Ødegård, J., and Klemetsdal, G.: Genetic associations between clinical mastitis and somatic cell score in early first-lactation cows, J. Dairy Sci., 89, 2236-2244, 2006.

Holdaway, R. J.: A comparison of methods for the diagnosis of bovine subclinical mastitis within New Zealand dairy herds: a thesis presented in partial fulfilment of the requirements for the degree of Doctor of Philosophy in veterinary clinic sccince at Massey University, Massey University, Massey, New Zealand, p. 413, 1990.

Hortet, P. and Seegers, H.: Calculated milk production losses associated with elevated somatic cell counts in dairy cows: review and critical discussion, Vet. Res., 29, 497-510, 1998.

Hortet, P., Beaudeau, F., Seegers, H., and Fourichon, C.: Reduction in milk yield associated with somatic cell counts up to
600.000 cells $\mathrm{mL}^{-1}$ in French Holstein cows without clinical mastitis, Livest. Prod. Sci., 61, 33-34, 1999.

ICAR: ICAR International agreement of recording practices, available at: http://www.icar.org/wp-content/uploads/2016/03/ Guidelines-Edition-2016.pdf (last access: 15 February 2017), 2016.

Jamrozik, J. and Schaeffer, L. R.: Test-day somatic cell score, fatto-protein ratio, milk yield, as indicators traits for sub-clinical mastitis in dairy cows, J. Anim. Breed. Genet., 129, 11-19, 2012.

Jamrozik, J., Bohmanova, J., and Schaeffer, L. R.: Relationships between milk yield and somatic score in Canadian Holsteins from simultaneous and recursive random regression models, J. Dairy Sci., 93, 1216-1233, 2010.

Jeretina, J., Ivanovič, B., Podgoršek, P., Perpar, T., Logar, B., Sadar, M., Jenko, J., Glad, J., Božič, A., Žabjek, A., Babnik, D., and Verbič, J.: Centralno podatkovna zbirka Govedo, Kmetijski inštitut Slovenije, Ljubljana, Slovenija, available at: http: //www.govedo.si (last access: 10 January 2017), 1997.

Jeretina, J., Babnik, D., and Škorjanc, D.: Modeling lactation curve standards for test-day milk yield in Holstein, Brown Swiss and Simmental cows, J. Anim. Plant Sci., 23, 754-762, 2013.

Knight, C. H. and Wilde, C. J.: Mammary cell changes during pregnancy and lactation, Livest. Prod. Sci., 35, 3-19, 1993.

Lescourret, F. and Coulon, J. B.: Modeling the impact of mastitis on milk production by dairy cows, J. Dairy Sci., 77, 2289-2301, 1994.

Miller, R. H., Paape, M. J., Fulton, L. A., and Schutz, M. M.: The relationship of milk somatic cell count to milk yields for Holstein heifers after first calving, J. Dairy Sci., 76, 728-733, 1993.

Nielsen, C., Østergaard, S., Emanuelson, U., Andresson, H., Berglund, B., and Strandberg, E.: Economic consequences of mastitis and withdrawal of milk with high somatic cell count in Swedish dairy herds, Animal, 4, 1758-1770, 2010.

Nyman, A.-K., Emanuleson, U., Gustafsson, A. H., and Persson Waller, K.: Management practices associated with udder health of first-parity dairy cows in early lactation, Prev. Vet. Med., 88, 138-149, 2009.

Nyman, A.-K., Persson Waller, K., Bennedsgaard, T. W., Larsen, T., and Emanuelson, U.: Association of udder-health indicators with cow factors and with intramammary infection in dairy cows, J. Dairy Sci., 97, 5459-5473, 2014.

Pantoja, J. C. F., Hulland, C., and Ruegg, P. L.: Dynamics of somatic cell counts and intrammamary infections across the dry period, Prev. Vet. Med., 90, 43-54, 2009.

Pyörälä, S: Indicators of inflammation in the diagnosis of mastitis, Vet. Res., 34, 565-578, 2003.

R Core Team, R: A language and environment for statistical computing, R Foundation for statistical computing, Vienna, Austria, available at: http://www.R-project.org, last access: 15 July 2016.

Rekik, B., Ajili, N., Belhani, H., Ben Gara, A., and Rouissi, H.: Effect of somatic cell count on milk and protein yields and female fertility in Tunisian Holstein dairy cows, Livest. Sci., 116, 309-317, 2008.

Rupp, R. and Boichard, D.: Relationship of early lactation somatic cell count with risk of subsequent first clinical mastitis, Livest. Prod. Sci., 62, 169-180, 2000.

Schepers, A. J., Lam, T. J. G. M., Schunkken, Y. H., Wilmink, J. B. M., and Hanekamp, W. J. A.: Estimation of vari- 
ance components for somatic cell counts to determine thresholds for uninfected quarters, J. Dairy Sci., 80, 1833-1840, 1997.

Schukken, Y. H., Wilson, D. J., Welcome, F., Garrison-Tikofsky, L., and Gonzales, R. N.: Monitoring udder health and milk quality using somatic cell counts, Vet. Res., 34, 579-596, 2003.

Seegers, H., Fourichon, C., and Beaudeau, F.: Production effects related to mastitis and mastitis economics in dairy cattle herds, Vet. Res., 34, 475-491, 2003.
Windig, J. J., Calus, M. P. L., De Jong, G., and Veerkamp, R. F.: The association between somatic cell count patterns and milk production prior to mastitis, Livest. Prod. Sci., 96, 291-299, 2005.

Wolfenson, D., Leitner, G., and Lavon, Y.: The disruptive effects of mastitis on reproduction and fertility in dairy cows, Ital. J. Anim. Sci., 14, 650-654, 2015.

Yalçin, C., Cevger, Y., Türkyilmaz K., and Uysal, G.: Estimation of milk yield losses from subclinical mastitis in dairy cows, Turk. J. Vet. Anim. Sci., 24, 599-604, 2000. 